\title{
Опрос ВБР датчиков с помощью когерентного оптического частотного рефлектометра на основе волоконного лазера с самосканированием длины волны
}

\author{
$\underline{\text { А.Ю. Ткаченко }}^{*}$ Н.Н. Смолянинов, М.И. Скворцов, \\ И.А. Лобач, С.И. Каблуков \\ Институт автоматики и электрометрии СО РАН, Новосибирск \\ *E-mail: alinka.tkacenko@yandex.ru
}

DOI: 10.31868/RFL2020.143-144

Распределенные измерения физических величин вдоль волоконнооптических линий могут быть осуществлены подходами оптической рефлектометрии [1], которая может быть как во временной, так и в частотной области. Принцип работы когерентной оптического частотного рефлектометра (КОЧР) основан на спектральном анализе интерференционного сигнала, возникающего при смешении зондирующего и рассеянного излучений. Данный анализ может осуществляться при перестройке оптической частоты непрерывного зондирующего излучения. В этом случае пространственная координата отражателей, расположенных вдоль исследуемой линии, пропорциональна частотной координате максимумов Фурье-спектра от измеренного в процессе перестройки оптической частоты интерференционного сигнала. В качестве основного элемента КОЧР предлагается использовать самосканирующий волоконный лазер. В лазерах такого типа оптическая перестройка частоты происходит без использования каких-либо перестраиваемых элементов. Лазер генерирует последовательность микросекундных высококогерентных (ширина линии 1 МГц) импульсов со спектральной, а изменение оптической частоты между импульсами обладает строгой дискретностью. В [2] была продемонстрирована пространственная дискретизация 200 мкм и чувствительность по коэффициенту отражения до $\sim 85$ дБ/мм при длине тестовой линии $\sim 9$ м. В данной работе представлены первые результаты демонстрирующие возможность применения КОЧР на основе волоконного лазера с самосканированием частоты для сенсорики.

Оптическая схема рефлектомера реализована на основе интерферометра Маха-Цендера, образованного тремя ответвителями. Одно из плеч интерферометра содержит сенсорную линию, состоящую из массива 28 ВБР с пиком отражения вблизи 1092 нм (нерезонансные) и одной ВБР с пиком отражения вблизи 1064 нм (резонансная) попадает в область перестройки самосканирующего лазера (1060-1080нм) в отличие от всех остальных ВБР. Линейная зависимость оптической частоты от номера импульса позволяет получить спектральную зависимость нормированной амплитуды сигнала интерференции. Рефлектограмма линии (на Рис.1), получалась в результате применения быстрого Фурье-преобразования к зависимости нормированного сигнала интерференции от оптической частоты. На Рис. 1а видно, что рефлектограмма состоит из множества пиков, при этом каждый соответствует отдельной ВБР. Видно, что амплитуда сигнала отражения резонансной ВБР выше, чем у нерезонансных. 


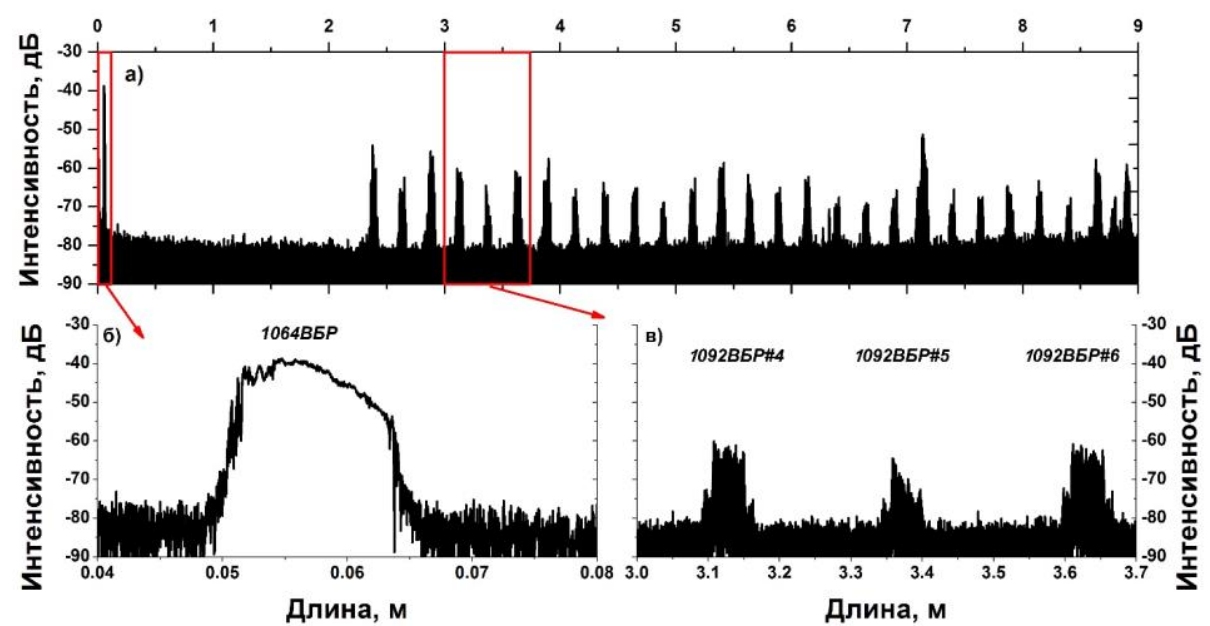

Рис.1. Рефлектограмма сенсорной линии в разных масштабах.

Для демонстрации сенсорных задач одна из нерезонансных ВБР помещалась в термостат, позволяющий производить нагрев до $100^{\circ} \mathrm{C}$. В экспериментах сравнивались корреляционные функции спектров отражения ВБР при комнатной температуре $\left(25^{\circ} \mathrm{C}\right)$ и в нагретом состоянии. Для исключения влияния случайного начала сканирования лазера проводился учет сдвига по корреляционному пику реперной ВБР, находящейся при комнатной температуре. Рис. 2 показывает смещение корреляционного узкого пика в область меньших частот при нагреве нерезонансной ВБР от 25 до $100^{\circ} \mathrm{C}$. Смещение корреляционного пика линейно связано с температурой с наклоном 1.83 ГГц/ ${ }^{\circ} \mathrm{C}$ $\left(0.73 \mathrm{HM} / 100^{\circ} \mathrm{C}\right)$.

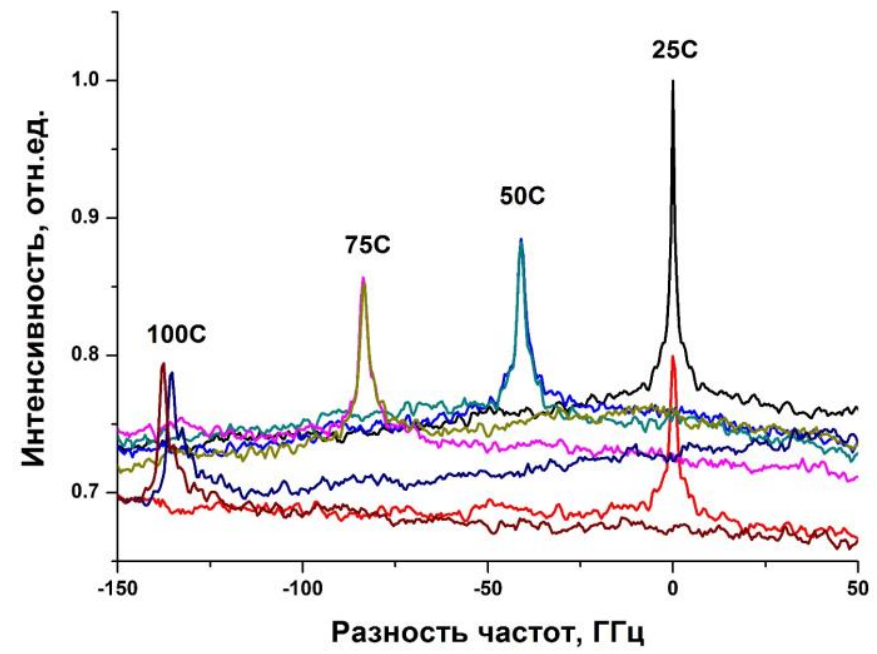

Рис. 2. Функции корреляции между спектрами отражения нерезонансной ВБР в процессе нагрева.

Подробное описание схемы КОЧР и полученных результатов будут представлены в докладе.

Экспериментальное исследование Ткаченко А.Ю. выполнено при финансовой поддержке РФФИ в рамках научного проекта № 18-32-00563. Работа выполнена в рамках темы гос.задания (№ гос. рег. АААА-А19-119112990054-4).

\section{Литература}

[1] A.H. Hartog, An Introduction to Distributed Optical Fibre Sensors CRC Press (2018)

[2] А.Ю. Ткаченко, И.А. Лобач, С.И. Каблуков, Квант. электрон., 49(12), 1121-1126, (2019) 